$\checkmark$ sciendo $\frac{\text { ECONOMIC THEMES (2021) 59(2): 173-191 }}{\text { DOI 10.2478/ethemes-2021-0010 }}$

\title{
ALIGNMENT WITH EU REGULATIONS IN THE FIELD OF THE COMPETITION POLICY AND SYSTEM OF STATE AID IN WESTERN BALKAN COUNTRIES
}

\author{
Boban Stojanović \\ University of Niš Faculty of Economics, Serbia \\ $\square d r . b o b a n . s t o j a n o v i c @ g m a i l . c o m$ \\ Zorana Kostić \\ University of Niš, Faculty of Mechanical Engineering, Serbia \\ $\triangle$ zorana.kostic@masfak.ni.ac.rs \\ Vladan Vučić \\ University Union-Nikola Tesla Belgrade, \\ Faculty of Law, Security and Management "Konstantin Veliki" Niš, Serbia \\ 凶vladan.vucic@gmail.com
}

UDC

339.137 .2

Review

paper

Received:

21.09.2020

Accepted:

28.02.2021

\begin{abstract}
The underying idea behand the foundation of the European Union is a single, integrated and competitive market. The future of the entire Western Balkans region (Albania, Bosnia and Herzegovina, Kosovo*, Montenegro, North Macedonia and Serbia) lies within the European Union. The main purpose of this paper is to explore the multiplicative effects of the alignment of European Union regulations with the competition policy in Western Balkan countries. In addition, the paper is designed to highlight the specific issues, challenges in this field, and provides an overview of empirical trends. A combination of qualitative and quantitative approach proposes methodological framework which recognizes different economic environments and regulatory frameworks. By comparing selected economic indicators related to competiton authorities (number of staff in the national authorities, annual budget of the national authorities, number of prohibited agreements, abuse of dominant position, notification of concentrations, opinions), the authors give a reliable basis for comparative progress analysis in this filed. Using multi-criteria optimization as a key method, as well as network and input-output display, the obtained results suggest country whose competition authority is efficient frontier. The significance of this research stems from the current debate whether the harmonized competition policy should speed up and facilitate the process of the accession of new member states to the European Union.
\end{abstract}

Keywords: competiton policy, system of state aid, European integration, Western Balkans, multicriteria optimization.

JEL classification: C61, C67, D40, K21. 


\section{Introduction}

The European Union's rules, which protect free competition, include antitrust rules against restrictive agreements between companies, abuse of dominant position, and rules on concentrations between companies, which would significantly impede competition. In addition, the European Union's rules also set out a system of state aid control. Governments are only allowed to grant state aid if restrictive conditions are met, with a view to preventing distortion of competition. Total amount of state aid in the European Union has been steadily rising due to the fact that it is used as one of the instruments aligned with a clear development vision. However, state aid cannot be a replacement for a substantially more supportive business environment.

Competition law doctrine has evolved and reacted to various challenges based on empirical evidence. Also, the stable core principles of European Union competition rules have ensured consistent enforcement. The basic framework of competition law, continues to provide sufficiently flexible basis for protecting competition in the digital era. However, the specific characteristics of platforms, digital ecosystems, and the data economy require the adoption and refinement of established concepts, doctrines and methodologies, as well as competition enforcement in general. Some researches show that the digital convergence should go towards intense integration process due to supporting digitalisation and innovation can push the Western Balkan region into faster convergence of economic development (Stojanović \& Kostić, 2018).

With regard to competition policy, the following options should be considered: taking into account third countries' state interventions in merger control; tackling excessive market power of big tech companies; modernising merger control; strengthening European joint ventures and cooperation; reinforcing advisory capacities and broadening the expertise; and encouraging behavioural remedies. The themes that have particular strategic importance are: protecting vulnerable consumers; improving trust in markets; promoting better competition in online markets; and supporting economic growth and productivity.

The main purpose of this paper is to investigate whether harmonized competition policy can speed up and facilitate the process of the accession of Western Balkan countries to the European Union. In addition, this paper addresses issues regarding the multiplicative effects of the alignment with European Union regulations in the field of the competition policy and system of state aid in Western Balkan countries as well as sustainability of the competition policy regime different economic environments.

This paper is organized as follows. After Introduction, comes Section 2 that emphasizes theoretical backgrounds and literature review which refer to the competition policy. Section 3 gives methodology framework and describes the 
data. Section 4 is devoted to the research results and discussions. In this section the authors describe the state of the competition policy effectiveness in Western Balkan countries. In addition, it gives State Aid Scoreboard and discusses empirical results at the European Union level in the period 2007-2018. Section 5 provides recommendations for further alignment with EU regulations in this field according to the European Commission Progress Report 2019 (European Commission, 2019). Finally, Section 6 provides the summary and conclusions.

\section{Theoretical backgrounds}

The competiton conditions determines the conduct and the level of the achieved performance of economic entities. In this regard, the structure-conductperformance paradigm (the SCP paradigm) is an analytical framework that establishes a causal relationship between market structure, conduct, and performance (Kostić et al., 2016). Taking into account that there is a two-way connection between innovations and competition, it can be noted that innovations encourage competition, and competitive pressure can force companies to continue innovating (Kostić, 2018). Antimonopoly policy makers face Market Imperfection - Market Failure dilemma (MI - MF dilemma). Proper resolution of the MI - MF dilemma is necessary to encourage companies to behave innovatively. The assessment of the MI-MF dilemma should be at the core of competition policy (Gaffard \& Quéré, 2006).

Some researchers point out that one of the key objectives of competition policy is to have influence on market structure and behavior that is considered socially undesirable (Žigić \& Maçi, 2011). Motta (2004) highlights that the effectiveness of competition policy can be determined by the extent to which it protects small and medium-sized enterprises, economic freedoms and promotes market integration. The speed of changes and the nature of the business environment affects the design of competition policy and the correct choice of measures and instruments of this policy (Audretsch et al., 2001).

Strategic documents and policies of the European Union, recognize industry as a key "engine" of recovery and growth. The competitive market conditions are the key to industrial development. In addition, important steps have been taken in the implementation and connection with the priorities and objectives of the Europe 2020 strategy which promotes modern technological solutions and innovative approaches (Kandžija et al., 2017). Generally speaking, the competition policy is an integral and prominent part of economic policy-making in every country. Economic analysis has been playing an increasingly significant role in the competition law cases. 
Figure 1 The integrated approach of the competition policy

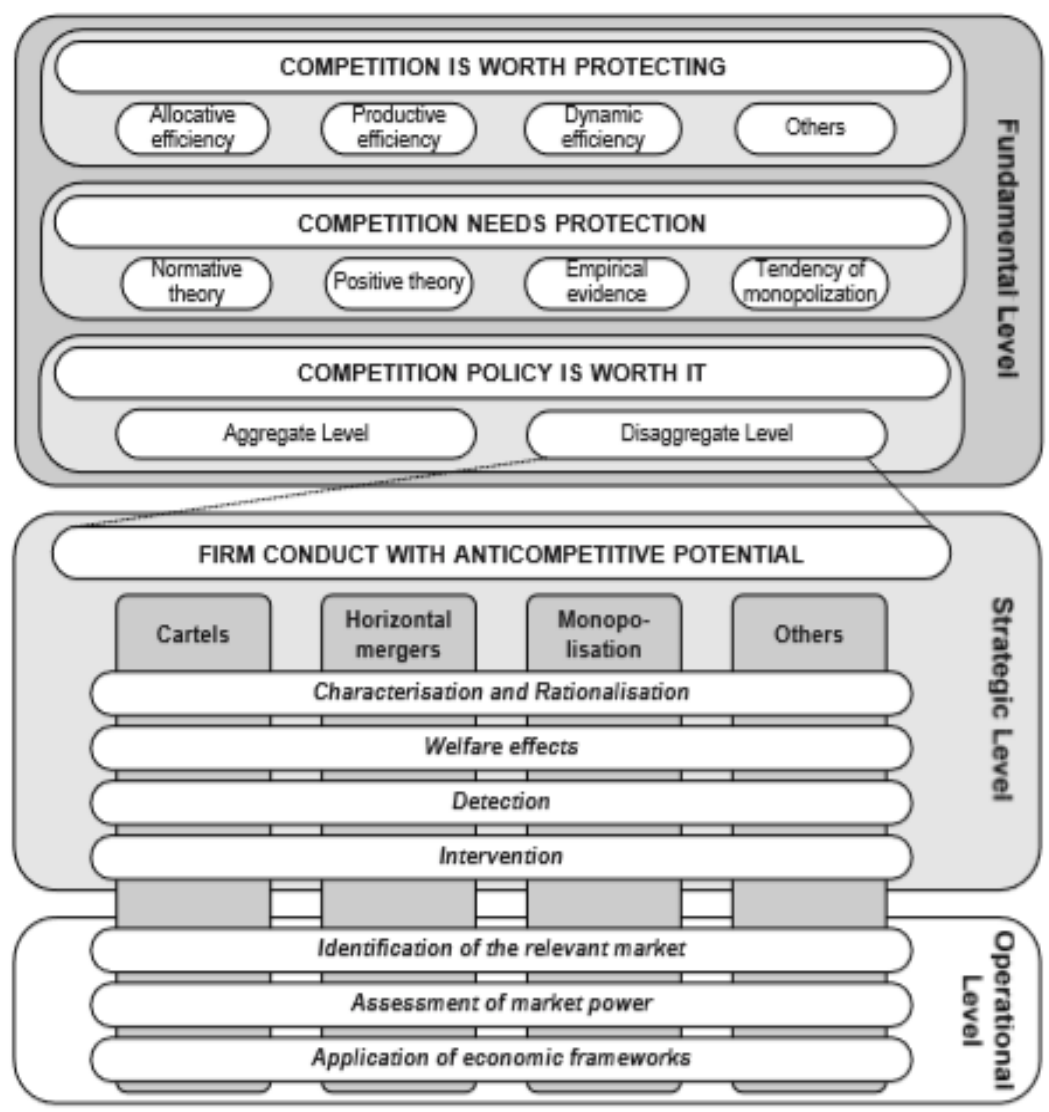

Source: Hüschelrath, K. (2009). Competition Policy Analysis: An Integrated Approach. ZEW Economic Studies (Publication Series of the Centre for European Economic Research (ZEW), Mannheim, Germany), Vol 41. Heidelberg: Physica-Verlag.

According to Hüschelrath (2009), the integrated approach of the competition policy includes: the fundamental level, the strategic level, and the operational level (Figure 1). Specifically, the fundamental level aims at answering existential questions of competition and competition policy. Consequently, the question is not whether it is the welfare-increasing that introduces competition policy, but rather whether (and how) it is possible to ameliorate it. The strategic level aims at developing a progression of necessary steps to assess whether and how certain business conducts should be subject to competiton policy. It is important to note that the strategic level aims at developing necessary analytical steps entirely from the viewpoint of applied microeconomics. Whereas the strategic level aims at constructing investigation frameworks from a largely normative economic 
perspective, the operational level focuses on the question of how a competiton authority should implement these recommendations in a world confined by resource constraints and asymmetric information. The integrated approach of the competition policy can be schematically shown as in the Figure 1.

Many authors agree that the institutional design of the competiton authorities provides a strong role for competiton advocacy, which would make markets more competitive, and that would allow for the restructuring of economies. In addition, the institutional design of the competiton authorities is related to the functions i.e. encompasses the dilemma between the single specialised or multiple functions. The most prominent dilemma is the inclusion of the state aid control function within the competencies of the existing competition authorities (Begović \& Popović, 2018).

Table 1 The institutional design of the competiton authorities

\begin{tabular}{|c|c|c|c|}
\hline & $\begin{array}{l}\text { Independence and } \\
\text { accountability }\end{array}$ & $\begin{array}{l}\text { Scope of the } \\
\text { enforcement power }\end{array}$ & $\begin{array}{l}\text { Investigative and } \\
\text { sanctioning } \\
\text { power }\end{array}$ \\
\hline $\begin{array}{l}\text { Institutional } \\
\text { Set up }\end{array}$ & $\begin{array}{l}\text { Administartive vs. } \\
\text { Judicial Model, } \\
\text { Independence of public } \\
\text { powers, } \\
\text { Organisational and } \\
\text { financial independence }\end{array}$ & $\begin{array}{l}\text { Antitrust prohibitions } \\
\text { and merger control, } \\
\text { Exclusion of sectors or } \\
\text { subjects, } \\
\text { Advocacy powers, } \\
\text { Consumer protection, } \\
\text { Other function }\end{array}$ & $\begin{array}{l}\text { Request for } \\
\text { information, } \\
\text { Inspection of } \\
\text { business and non- } \\
\text { business premises, } \\
\text { Interim measures, } \\
\text { Sanctions for main } \\
\text { violations, } \\
\text { Sanctions to back } \\
\text { up ancillatory } \\
\text { provisions }\end{array}$ \\
\hline & $\begin{array}{c}\text { Interpretation of the } \\
\text { substantive rules }\end{array}$ & Sanction policy & Setting priorities \\
\hline Implementation & $\begin{array}{l}\text { Guidelines on market } \\
\text { definition, } \\
\text { Presumptions and } \\
\text { evidence }\end{array}$ & $\begin{array}{l}\text { Criteria for finesetting, } \\
\text { Aggravating and } \\
\text { alleviating } \\
\text { circumstances, } \\
\text { Leniency programme, } \\
\text { Compliance } \\
\text { porgramme, } \\
\text { Commitment decision, } \\
\text { Settlement }\end{array}$ & $\begin{array}{l}\text { Enforcenment vs. } \\
\text { Advocacy, } \\
\text { Types of } \\
\text { infringenment, } \\
\text { Sectors, } \\
\text { Strategy plans vs. } \\
\text { informal } \\
\text { statements }\end{array}$ \\
\hline
\end{tabular}

Source: Buccirossi, P. \& Ciari, L. (2018). Western Balkans and the Design of Effective Competition Law: The Role of Economic, Institutional and Cultural Characteristics. (quoted in: Begović, B. \& Popović, D. V. (Eds.). Competition Authorities in South Eastern Europe. Springer Open, Cham, pp. 16. 
The institutional design of the competiton authorities can analyzed from the aspect of institucional set up and implementation (Table 1). On the one hand, three important fields for considering institutional set up are: independence and accountability, scope of the enforcement power, investigative and sanctioning power. On the other hand, Table 1 shows that successful implementation of competition law depends on interpretation of the substantive rules, sanction policy and setting priorities of the competiton authorities.

Recent analyses in this area are reconsidering wheather the South East European countries have met the competiton low related requirements stemming from the Stabilization and Association Agreements and the CEFTA Agreement, and whether the existing mechanisms are applicable in case non-compliance with the said requirements are effective. It can be observed that South East European countries have harmonised their competition ligislation with that of the European Union to a high extent. Unfortunately, these rules are being enforced by competition authorities of dubious independence from the national Government (Popović, 2018).

\section{Methodology and Data Specification}

The methodological base of the paper refers to the data from the European Commission, and the national competiton authorities reports for selected group of countries (Albania, Bosnia and Herzegovina, Kosovo*, Montenegro, North Macedonia and Serbia). Selected indicators in the research are related to competiton authorities (number of staff in the national authorities, annual budget of the national authorities, number of prohibited agreements, abuse of dominant position, notification of concentrations, opinions). The special attention in the paper is paid to the structure of state aid per type of goals it achieves. Taking into account the selected indicators, the comparative analysis of the competition policy effectiveness in Western Balkan countries was observed. On that data basis, the paper highlights recommendations for further alignment with European Union regulations in the field of the competition policy and system of state aid in Western Balkan countries.

In this regard, in order to carry out multicriteria analysis of the competition policy in Western Balkan countries, the Promethee method is preferred. Visual Promethee software is used as a multicriteria decision aid in order to evaluate several possible decisions or items according to multiple often conflicting criteria, to identify the best possible decision, and to rank possible decisions from the best to the worst one (Radukić et al., 2019). There are two Promethee rankings:

[1] the Promethee I Partial Ranking is based on the computation of two preference flows (Phi+ and Phi -). It allows for incomparability between actions when both Phi+ and Phi- preference flows give conflicting rankings; 
[2] the Promethee II Complete Ranking is based on the net preference flow (Phi).

The Promethee method is designed to analyze data within a multicriteria table including: a number of actions (countries), and several criteria (selected indicators). In mathematical terms the problem is the following:

$$
\max \left\{f_{1}(a), f_{2}(a), f_{3}(a), \ldots, f_{n}(a)\right\} \mid a \in A
$$

where $A$ is a finite set of $n$ actions and $f_{l}$ to $f_{k}$ are $k$ criteria. Some criteria can be maximized or minimized. The evaluations of the actions on the criteria form a twoway multicriteria table is set as:

\begin{tabular}{c|ccccc} 
& $f_{1}$ & $f_{2}$ & $f_{3}$ & $\ldots$ & $f_{n}$ \\
\hline$a_{1}$ & $f_{1}\left(a_{1}\right)$ & $f_{2}\left(a_{1}\right)$ & $f_{3}\left(a_{1}\right)$ & $\ldots$ & $f_{n}\left(a_{1}\right)$ \\
$a_{2}$ & $f_{1}\left(a_{2}\right)$ & $f_{2}\left(a_{2}\right)$ & $f_{3}\left(a_{2}\right)$ & $\ldots$ & $f_{n}\left(a_{2}\right)$ \\
$a_{3}$ & $f_{1}\left(a_{3}\right)$ & $f_{1}\left(a_{3}\right)$ & $f_{1}\left(a_{3}\right)$ & $\ldots$ & $f_{n}\left(a_{3}\right)$ \\
$\cdot$ & $\cdot$ &. &. &. & $\cdot$ \\
$\cdot$ &. &. &. &. & $\cdot$ \\
$\cdot$ & $\cdot$ &. &. &. & $\cdot$ \\
$a_{m}$ & $f_{1}\left(a_{m}\right)$ & $f_{2}\left(a_{m}\right)$ & $f_{3}\left(a_{m}\right)$ & $\ldots$ & $f_{n}\left(a_{m}\right)$
\end{tabular}

It is important to point out that the expectation of the decision-maker is to identify an action that is optimal on all the criteria at the same time. Hence, this is usually impossible as the criteria are more or less conflicting with each other. In order to achieve this objective, it is essential to have some information about the preferences and the priorities of the decision-maker. It should not ignore the fact that different decision-makers will have different preferences and priorities. Therefore, to solve the problem, all criteria can be aggregated into a single summary score and to compute a weighted sum or weighted average of the evaluations:

$$
V(a)=\sum w_{n} * f_{n}(a)
$$

where $\mathrm{w}_{\mathrm{i}}>0$ is the weight allocated to criterion $\mathrm{f}_{\mathrm{j}}$ (the more important $\mathrm{f}_{\mathrm{j}}$ the larger $\left.\mathrm{w}_{\mathrm{j}}\right), \cdot V(a)$ is the resulting score of action $a$. The actions can then be ranked according to their $\mathrm{V}$ score, from the largest to the smallest value. During the analysis, the same importance is given to all selected criteria (indicators). 


\section{Research results and discussion}

This part of the paper presents topical insights into the main empirical results regarding to the comparative analysis of the compettion policy effectiveness in Western Balkan countries, and the state aid scoreboard in the European Union.

Understanding the benefits of the digital economy, ensuring market competition and access, focusing more on consumers should be a priority for all countries. New initiatives to modify and expand existing rules and policies should be presented and the regulatory framework should be aligned at all levels. In addition to rising competition, security and data privacy issues represent important questions and challenges (Franc, 2019).

\subsection{The comparative analysis of the competition policy effectiveness in Western Balkan countries}

In negotiation process regarding the accession of new meber states to the European Union, all Western Balkan countries will face a request related to new legislation and the independence of the State Aid Control Commission. Due to the Government's unwillingness to relinquish its powers in granting state aid, this chapter will be opened at the last and closed at the end of the negotiation process. Better situation is in the other part of the field of competition protection, which is mostly covered by negotiation chapter. Preparations are underway for the adoption of the new competition law. This should strengthen the action of the Competition Commission.

Table 2 General Information about Competition Authorities in Western Balkan countries

\begin{tabular}{|l|c|c|c|c|}
\hline \multicolumn{1}{|c|}{$\begin{array}{c}\text { Competition } \\
\text { Authorities }\end{array}$} & $\begin{array}{c}\text { The first } \\
\text { Competition } \\
\text { Act }\end{array}$ & $\begin{array}{c}\text { Year of } \\
\text { Constitution }\end{array}$ & $\begin{array}{c}\text { Annual Budget } \\
\text { (2018) EUR }\end{array}$ & $\begin{array}{c}\text { Number } \\
\text { of Staff }\end{array}$ \\
\hline Albania & 2003 & 2003 & $531,522.00$ & 39 \\
\hline $\begin{array}{l}\text { Bosnia and } \\
\text { Herzegovina }\end{array}$ & 2001 & 2004 & $699,447.00$ & 26 \\
\hline Kosovo* & 2004 & 2009 & $332,409.00$ & 23 \\
\hline Montenegro & 2012 & 2016 & $482,000.00$ & 19 \\
\hline $\begin{array}{l}\text { North } \\
\text { Macedonia }\end{array}$ & 2005 & 2005 & $357,000.00$ & 29 \\
\hline Serbia & 2005 & 2005 & $1,000,000.00$ & 47 \\
\hline
\end{tabular}

Source: Authors' presentation according to national reports. 
General Information about Competition Authorities in Western Balkan countries (Albania, Bosnia and Herzegovina, Kosovo*, Montenegro, North Macedonia and Serbia) is given in the Table 2. In addition, statistical data about competition cases (prohibited agreements, abuse of dominant position, Nntification of concentrations, opinions) is presented in the Table 3. Total competition cases for selected group of countries are calculated according to national reports.

Table 3 Statistical data about Competition Cases by countries

\begin{tabular}{||l|c|c|c|c|c||}
\hline \multicolumn{1}{|c|}{2018} & $\begin{array}{c}\text { Prohibited } \\
\text { agreements }\end{array}$ & $\begin{array}{c}\text { Abuse of } \\
\text { dominant } \\
\text { position }\end{array}$ & $\begin{array}{c}\text { Notification of } \\
\text { concentrations }\end{array}$ & Opinions & Total \\
\hline Albania & 2 & 2 & 13 & 21 & 38 \\
\hline $\begin{array}{l}\text { Bosnia and } \\
\text { Herzegovina }\end{array}$ & 6 & 8 & 12 & 6 & 32 \\
\hline Kosovo* & 4 & 2 & 4 & 1 & 11 \\
\hline Montenegro & 6 & 5 & 2 & 8 & 21 \\
\hline $\begin{array}{l}\text { North } \\
\text { Macedonia }\end{array}$ & 7 & 7 & 50 & 3 & 67 \\
\hline Serbia & 5 & 3 & 49 & 7 & 64 \\
\hline
\end{tabular}

Source: Authors' presentation according to national reports.

The state aid system and its structure in Western Balkan countries is substantially different from that in the European Union. Reporting is very nontransparent. The work of the Regulatory Authorities is not independent. For example, in Serbia the State Aid Commission is financially dependent on the Ministry of Finance, and the Commission's decisions are almost without exception positive.

A multi-criteria optimization was applied to ranked countries, as a key method for assessing the competition policy effectiveness in Western Balkan countries. The analysis of the significance of the criteria includes determining the weight coefficients. It should be noted here that all six criteria (number of staff, annual budget, number of prohibited agreements, abuse of dominant position, notification of concentrations) are given equal importance in the analysis which covered six countries. The authors used U-shape preference function. Based on the network and input-output display, it can be conculed that Serbian competition authority is the most effective in the whole region, measured by selected indicators. Also, the Serbian competion authority is efficient frontier. 
Figure 2 Promethee network and Input-Output Efficient Frontier
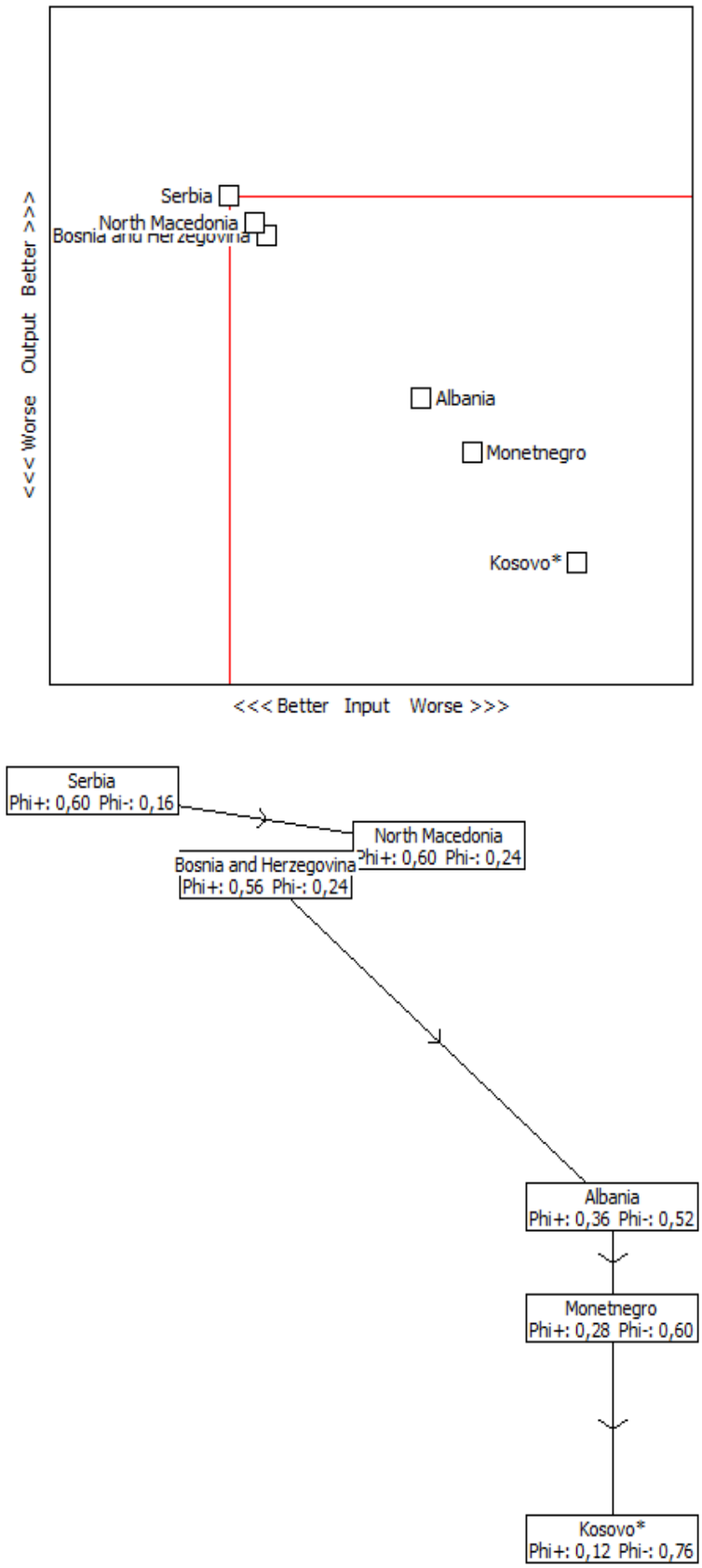

Source: Authors' own presentation. 
The Figure 2 shows network and input-output efficient frontier, which are obtained by using multicriterial decision-making software Visual Promethee. The Promethee Network is representation of the Promethee I Partial Ranking. In addition, Figure 2 shows a two-dimensional representation of the input and output flows of the competition cases. Serbia is the efficient frontier with quite different competition authorities performance profile compared to other countries. Serbia is followed by North Macedonia, Bosnia and Herzegovina, Albania, Montenegro, and Kosovo* respectively.

The competiton advocacy is a very effective tool for sustainable competiton policy. Therefore, the role of the economic analysis in competiton law enforcement is essential. In his contribution to the topic, Plahutnik (2018) highlights that institutional capacities represent an important element for the implementation, either in the form of the competiton law enforcement or in the form of competition advocacy (Begović \& Popović, 2018, 79-91). Also, he concluded that efficient institutions are not dependent on the number of staff, but on the qualification, good management and full independence from political and economic influence. In addition, political influence with regard to state aid most likely cannot be avoided.

\subsection{State Aid Scoreboard and empirical results in the European Union}

State aid is defined as an advantage in any form whatsoever conferred on a selective basis to undertakings by national public authorities. Therefore, subsidies granted to individuals or general measures open to all enterprises are not covered by this prohibition and do not constitute State aid (examples include general taxation measures or employment legislation). A company which receives government support gains an advantage over its competitors. Therefore, the Treaty generally prohibits state aid unless it is justified by reasons of general economic development (Treaty on the Functioning of the European Union) ${ }^{1}$. To ensure that this prohibition is respected and exemptions are applied equally across the European Union, the European Commission is in charge of ensuring that state aid complies with the European Union's rules. The purpose of the transparency requirements is to promote accountability of granting authorities and to reduce asymmetries on the market for state aid. In order to be identified as state aid, a measure needs to have four features:

[1] there has been an intervention by the State or through State resources which can take a variety of forms (e.g. grants, interest and tax reliefs, guarantees, government holdings of all or part of a company, or providing goods and services on preferential terms, etc.);

[2] the intervention gives the recipient an advantage on a selective basis, for example to specific companies or industry sectors, or to companies located in specific regions; 
[3] competition has been or may be distorted;

[4] the intervention is likely to affect trade between Member States (Treaty on the Functioning of the European Union).

In order to emphasize the comparative analysis in the field of state aid per type of objective in the European Union member states, and non member states, the Figure 3 is given in the paper. Therefore, classification is given respecting the division between core countries, south periphery, and non member states (Figure 3). Take into account objectives (regional development, environmental protection or sectoral development and restructuring), has great significance in the economic analysis of the state aid. Also, Figure 3 shows the divergent results in different groups of countries, which indicates the fact that countries achieve different goals by using state aid instruments.

Figure 3 State aid per type of objective in \% of GDP

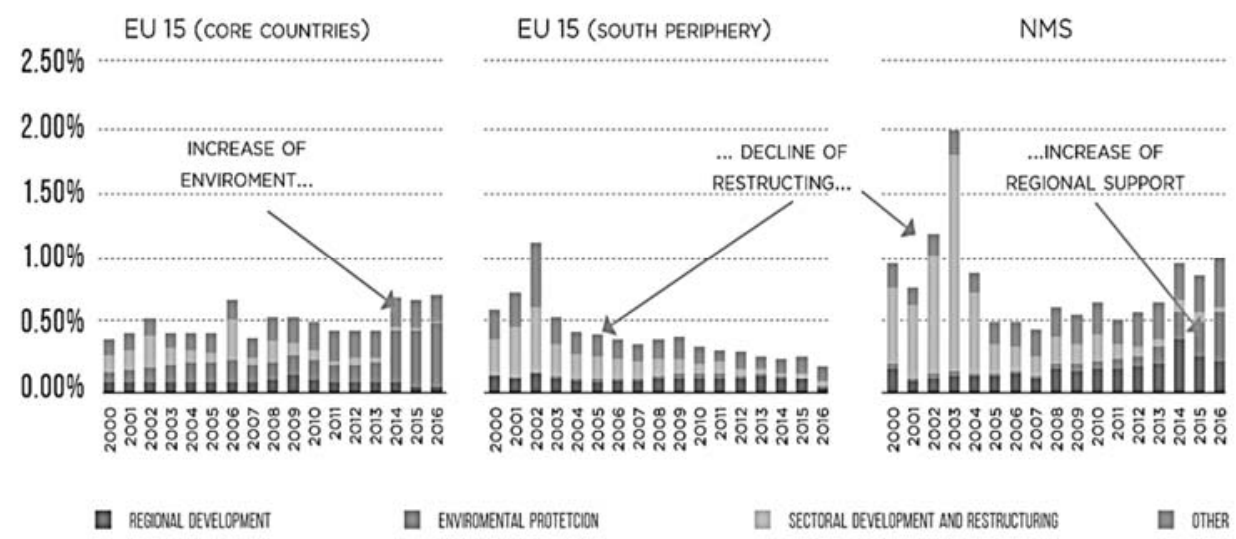

Source: Center for Advanced Economic Studies (CEVES) (2019). Alignment with EU

Regulations for Enhanced Development Effectiveness of State Aid. Belgrade. p.19.

Total amount of state aid in the European Union reached on average EUR 66bn over the period 2000-2016, and until 2006 had been mostly allocated in support of industrial restructuring, sectoral and regional development. Total amount of state aid in EU-28 was steadily rising from $0.48 \%$ of GDP (EUR 46bn) in 2000 to $0.65 \%$ of GDP (almost EUR 100bn) in 2016. Until 2006 most of it had been directed to industrial restructuring, and sectoral and regional development, a trend especially strong in Central, Eastern and Southeastern Europe. 


\section{Recommendations for further alignment with EU regulations in the field of the competition policy and system of state aid in Western Balkan countries}

Albania has some level of preparation or is moderately prepared for competition policy. There was some progress during the reported period, in particular in legislative alignment with the acquis. However, significant efforts must be reinforced to further improve legislative alignment with the acquis and to implement state aid rules. In line with previous recommendations, the operational independence of the State Aid Commission (SAC) has not yet been ensured. Furthermore, the SAC needs to redouble efforts to improve its enforcement record. In the coming year, the country should in particular:

- significantly increase the administrative capacity of SAC's secretariat, which currently raises serious concerns;

- ensure the operational independence of the State Aid Commission;

- raise awareness of the SAC with respect to line ministries, regional and local authorities in order to ensure prior notification of aid measures and strengthen the enforcement of state aid rules.

Bosnia and Herzegovina has some level of preparation in the area of competition policy. Bosnia and Herzegovina should continue to further align its legislative framework in the area of competition and state aid with the relevant parts of the Acquis. In the coming year, the country should pay particular attention to the following actions:

- revise its decision-making procedures, remove ethnic vetoes, and amend the procedural deadlines to allow sufficient time for adopting decisions. The procedures for appointing the members of the Council need to be simplified. Similarly, the decision-making procedures of the State Aid Council need to be revised to remove ethnic vetoes.

- The State Aid Council needs to demonstrate its operational independence and build a solid track record of enforced decisions. To this end, the country should significantly strengthen the administrative capacity of the State Aid Council and step up efforts to raise awareness about state aid rules at all levels.

- In the coming period, Bosnia and Herzegovina should in particular: improve the enforcement record of the State Aid Council by ensuring that state aid measures are notified ex ante by granting authorities; align the existing aid schemes; ensure that the State Aid Council is operationally independent and obtains adequate financing, including outstanding contributions from the Republika Srpska entity.

Montenegro is moderately prepared in this area. Some progress was registered, in particular by completing the set-up of the independent state aid authority. Montenegro has a good level of preparation as regards alignment with the EU 
acquis on antitrust and mergers. The State aid legislative framework is to a large extent aligned with the EU acquis. Further significant efforts are needed for the enforcement of the antitrust, mergers and state aid legislation. In the coming year, Montenegro should pay particular attantion to the following:

- ensure the functioning of the state aid authority, now placed in the Agency for the Protections of Competition, and the effectiveness of its control on state aid at all levels, including the building up of an enforcement record;

- ensure transparency on all state aid decisions;

- improve the track record of the Agency for the Protection of Competition on antitrust and mergers.

North Macedonia is moderately prepared in the area of competition policy. No progress has been made in this field through 2018. As none of last year's recommendations have been addressed, they remain valid. Significant efforts should be reinforced. In the coming year, the country should pay particular attention to the following:

- step up the enforcement record of the Commission for the Protection of Competition;

- increase the transparency of State aid granted by the government;

- ensure independence and capacity of the Commission for the Protection of Competition.

Kosovo* is at an early stage of competition. Some progress was made by adopting the Law on State Aid and by adopting secondary legislation in competition law. However, as most of last year's recommendations have not been addressed, they remain valid. The agencies responsible for competition and state aid face substantial challenges to their investigative and decision-making capacity. Significant efforts are needed to improve legislative alignment and enforcement. Kosovo* should pay particular attention in the coming year to the following:

- strengthen the enforcement of competition and state aid law;

- complete the alignment of implementing legislation on competition and state aid;

- ensure the functional capacity and operational independence of the competition and state aid institutions in charge of development and enforcement at all levels.

Serbia has some level of preparation/is moderately prepared in the area of competition policy. No progress has been made in the field of legislative alignment and enforcement of state aid rules. In the coming year Serbia should in particular:

- make significant progress in the alignment with legislation on state aid, in particular repealing the exemption of companies in the process of privatisation from State aid rules, in line with its obligations under the Stabilisation and Association Agreement (SAA); 
- take additional steps to align existing schemes, in particular the fiscal state aid schemes (namely the Law on corporate income tax, the Law on personal income tax and the Law on free zones) with the acquis;

- increase substantially the budget of the Commission for State Aid Control (CSAC), as well as its enforcement powers, to ensure its independence and effectiveness;

- align the law on multilateral interchange fees and special operating rules for card-based payment transactions with the acquis and SAA obligations.

Table 3 summarizes European Commission progress results in the field of competition policy by selected countries. As can be seen from Table 3, special attention is paid to the results related to stage of competiton, adaption of law, enforcement capacity, and state aid.

Table 3 Summary of the European Commission Progress Reports 2019 in the field of competition policy by selected countries

\begin{tabular}{|l|c|c|c|c||}
\hline \multicolumn{1}{|c|}{ Countries } & $\begin{array}{c}\text { Stage of } \\
\text { competiton }\end{array}$ & $\begin{array}{c}\text { Adaption } \\
\text { of Law }\end{array}$ & $\begin{array}{c}\text { Enforcement } \\
\text { Capacity }\end{array}$ & State Aid \\
\hline Albania & $\begin{array}{c}\text { Moderate } \\
\text { preparation }\end{array}$ & $\begin{array}{c}\text { Some } \\
\text { progress }\end{array}$ & Adequate & Inefficient \\
\hline $\begin{array}{l}\text { Bosnia and } \\
\text { Herzegovina }\end{array}$ & Early stage & $\begin{array}{c}\text { Not fully } \\
\text { aligned }\end{array}$ & $\begin{array}{c}\text { Lack of the required } \\
\text { expertise }\end{array}$ & $\begin{array}{c}\text { Partially aligned } \\
\text { with EU }\end{array}$ \\
\hline Kosovo* & Early stage & $\begin{array}{c}\text { Some } \\
\text { progress }\end{array}$ & Inefficient & Limited \\
\hline Montenegro & $\begin{array}{c}\text { Moderate } \\
\text { preparation }\end{array}$ & $\begin{array}{c}\text { Some } \\
\text { progress }\end{array}$ & $\begin{array}{c}\text { Inefficient and } \\
\text { inadequate }\end{array}$ & $\begin{array}{c}\text { Partly aligned with } \\
\text { EU }\end{array}$ \\
\hline $\begin{array}{l}\text { North } \\
\text { Macedonia }\end{array}$ & $\begin{array}{c}\text { Moderate } \\
\text { preparation }\end{array}$ & $\begin{array}{c}\text { No } \\
\text { progress }\end{array}$ & $\begin{array}{c}\text { Level of expertise } \\
\text { inadequate }\end{array}$ & Inadequate \\
\hline Serbia & $\begin{array}{c}\text { Moderate } \\
\text { preparation }\end{array}$ & $\begin{array}{c}\text { Some } \\
\text { progress }\end{array}$ & Inefficient & No progress \\
\hline
\end{tabular}

Source: Authors' presentation according to European Commission data.

In general, there are particular rules, obligations and rights that justify potential restrictions of different market behaviors that would lead to economic benefits for the whole society. "Therefore, the question is not whether public interest should be taken into account when considering different competition policies, but rather the nature and level of any competition restriction, as well as its effect on the whole society. It is also of great significance to insist on a transparent discussion of public interest in the domain of protection of competition, encompassing all parties involved" (Obradović et al., 2019). Discussions should be complemented by serious responsibility of policy-makers and hence ensure timely and most appropriate competition policies which would reflect the defined economic objectives. 


\section{Conclusion}

Competition gives companies incentives to innovate, enter new market, improve efficiency, greater choice of possibilities, and lower prices for consumers, which cumulatively observed, makes companies more competitive in world markets. State aid control helps rewarding the most competitive companies, thereby increasing overall competitiveness. It also presents an efficient use of taxpayers' money while maximizing available resources from limited national budgets targeting many essential purposes, such as the educational system, the health system, national security, social protection and others. State aid control ensures that any detriment arising from distortions of competition is outweighed by the public purpose pursued by the aid. Moreover, by steering public aid towards objectives of common interest that otherwise would not be realized, state aid control helps both ensuring benefits for society and minimizing the negative impact of the distortion of competition.

All Western Balkan countries have some level of preparation and they are moderately prepared in competition policy. There is a lot to do in the next period in order to create an adequate competition regime. Better alignment with the European Union Acquis and regulation would ensure greater development effectiveness of competition policy and system of state aid.Based on the network and input-output display, it can be conculed that Serbian competition authority is the most effective in the whole region, measured by selected indicators (number of staff in the national authorities, annual budget of the national authorities, number of prohibited agreements, abuse of dominant position, notification of concentrations).

It can be concluded that competition policy and state aid need to be used as instruments aligned behind a clear development vision for Western Balkan region. In other words, our analysis suggests that competion protection and state aid rules will continue to be relevant for future industrial policies in Western Balkan countries, regardless of the outcome of the current European integration process. Finally, the national authorities must give continuous attention to building a competition culture.

By using multi-criteria optimization, i.e. network and input-output display, the the main findings show that, country whose competition authority is efficient frontier, can speed up process of the accession to the European Union. Such convergent movements confirm the research question that the harmonized competition policy should facilitate the further integration process.

The future reseach could deal with the issue whether public interest should be taken into account when considering different competition policies. Discussions should include timely and most appropriate competition policies which would reflect the defined economic objectives and total social welfare. 


\section{References}

Audretsch, D. B., Baumol, W. J. \& Burke, A. E. (2001). Competition policy in dynamic markets. International Journal of Industrial Organization, Vol. 19 (5), pp. 613-634.

Begović, B. \& Popović, D. V. (Eds.) (2018). Competition Authorities in South Eastern Europe: Building Institutions in Emerging Markets. Cham: Springer Open.

Buccirossi, P. \& Ciari, L. (2018). Western Balkans and the Design of Effective Competition Law: The Role of Economic, Institutional and Cultural Characteristics. (quoted in: Begović, B. \& Popović, D. V. (Eds.). Competition Authorities in South Eastern Europe. Springer Open, Cham, pp. 7-41).

Center for Advanced Economic Studies (CEVES) (2019). Alignment with EU Regulations for Enhanced Development Effectiveness of State Aid. Belgrade.

European Commission (2019). Progress Reports 2019, Brussels, available at: https:/europeanwesternbalkans.com/2019/05/29/european-commission-publisheswb-progress-reports, accessed on: March 15, 2020.

Franc, S. (2019). Digital trade as an impetus for new regulatory initiatives. Ekonomski Vjesnik, Vol. 32, No.1, Faculty of Economics in Osijek, J. J. Strossmayer University of Osijek, pp. 219-228.

Gaffard, J. \& Quéré, M. (2006). What's the aim for competition policy: optimizing market structure or encouraging innovative behaviors? Journal of Evolutionary Economics, 16(1/2), pp. 175-187. DOI: 10.1007/s00191-005-0014-0.

Hüschelrath, K. (2009). Competition Policy Analysis: An Integrated Approach. ZEW Economic Studies (Publication Series of the Centre for European Economic Research (ZEW), Mannheim, Germany), Vol 41. Heidelberg: Physica-Verlag.

Kandžija, V., Tomljanović, M. \& Huđek, I. (2017). Deindustrialization as a process in the EU. Ekonomski Vjesnik, Vol. 30, No. 2, pp. 399-414.

Kostić, Z. (2018). Innovations and digital transformation as a competition catalyst. Ekonomika Vol. 64 (1), pp.13-23. doi:10.5937/ekonomika1801013K

Kostić, Z., Stojanović, B. \& Radukić, S. (2016). Measuring the Level of Competition on the Serbian mobile Telecommunications Market. Economic Themes 54(3), Faculty of Economics University of Niš, pp. 323-343.

Motta, M. (2004). Competition Policy: Theory and Practice. New York: Cambridge University Press.

Obradović, M., Lončar, D., Stojanović, F. \& Milošević, S. (2019). Public interest consideration in competition policy. Ekonomika preduzeća, Vol. 67, No.1-2, pp. 167-179.

Popović, V. D. (2018). Legal Implications of Trade Liberalization under SAAs and CEFTA. Belgrade: University of Belgrade, Faculty of Law.

Radukić, S., Mastilo, Z., Kostić, Z. \& Vladušić, L. (2019). Measuring of the goods and labor markets efficiency: Comparative study of Western Balkan countries. Montenegrin Journal of Economics, 15(2), pp. 95-109.

Stojanović, B. \& Kostić, Z. (2018). Convergence Challenges in Digital Business Environment of Western Balkan Countries. (quoted in: Ivana Domazet, Mirjana Radović-Marković, Aleksandra Bradić-Martinović, Institute of Economic Sciences, Belgrade, Serbia (Eds.). Digital Transformation New Challenges and Opportunities, London: Silver and Smith Publishers, pp. 31-52). 
Treaty on the Functioning of the European Union - Part three: Union policies and internal actions - Title VII: Common rules on competition, taxation and approximation of laws - Chapter 1: Rules on competition - Section 2: Aids granted by States - Article 107 (ex Article 87 TEC).

Žigić, K. \& Maçi, I. (2011). Competition policy and market leaders. Economic Modelling, Vol. 28, pp. 1042-1049. DOI:10.1016/j.econmod.2010.11.024.

\section{USKLAĐIVANJE SA PROPISIMA EU U OBLASTI POLITIKE KONKURENCIJE I SISTEMA DRŽAVNE POMOĆI U ZEMLJAMA ZAPADNOG BALKANA}

Apstrakt: Ideja koja podupire temelj Evropske unije je jedinstveno, integrisano $\mathrm{i}$ konkurentno tržište. Budućnost čitavog regiona Zapadnog Balkana (Albanija, Bosna i Hercegovina, Kosovo*, Crna Gora, Severna Makedonija i Srbija) je u Evropskoj uniji. Glavna svrha ovog rada je da istraži multiplikativne efekte usklađivanja sa propisima Evropske unije u oblasti politike konkurencije u zemljama Zapadnog Balkana. Pored toga, u radu se ističu specifična pitanja, izazovi u ovoj oblasti i empirijski trendovi. Kombinacijom kvalitativnog i kvantitativnog pristupa predlaže se metodološki okvir koji prepoznaje različita ekonomska okruženja i regulatorne okvire. Upoređivanjem odabranih ekonomskih pokazatelja koji se odnose na nadležna tela u oblasi konkurencije (broj zaposlenih, godišnji budžet, broj zabranjenih sporazuma, broj zloupotreba dominantnog položaja, broj obaveštavanja o koncentracijama, broj datih mišljenja), autori daju pouzdanu osnovu za komparativnu analizu $u$ ovoj oblasti. Korišcenjem višekriterijumske optimizacije kao ključne metode, kao i mrežnog i ulazno-izlaznog prikaza, dobijeni su rezultati koji sugerišu zemlju čije je nacionalno telo za zaštitu konkurencije najefikasnije. Značaj ovog istraživanja proizilazi iz trenutne rasprave o tome da li usklađena politika zaštite konkurencije može da ubrza i olakša proces pristupanja novih država članica Evropskoj uniji.

Ključne reči: politika zaštite konkurencije, sistem državne pomoći, evropske integracije, Zapadni Balkan, višekriterijumska optimizacija 


\section{Authors' biographies}

Boban Stojanović, PhD, is a full professor at the Faculty of Economics in Niš. He teaches Theory and Policy of Prices, Macroeconomics, and Microeconomic Models. $\mathrm{He}$ is also appointed to teach Contemporary Microeconomic Analysis at the doctoral level. He lectured on Theory of Prices, and Theory of Production at the Faculty of Economics in Belgrade. He also taught at the Kazakh National University Almaty, Kasakhstan, Summer schools at University Sophia Antipolis, Nice, France and University Freiberg, Germany. He is President of the Niš Association of Economists, a member of the Executive Committee and presidential board of the Serbian Association of Economists.

Zorana Kostić, PhD, is an assistant professor at the Faculty of Mechanical Engineering, University of Niš. She worked as research associate at the Faculty of Sciences and Mathematics, University of Niš. As a scholar of the Ministry of Education, Science and Technological Development of the Republic of Serbia, she worked as a teaching assistant on subjects Microeconomics, and Theory and Policy of Prices at the Faculty of Economics, University of Niš. She worked at Ministry of Finance, and gains international experience through study visits at Paderborn University and Regensburg University in Germany, State University of Technology "Shuhov" in Belgorod, Russia, and Donetsk National University in Ukraine. She is an author of numerous scientific papers. Her scientific interest is related to the industrial organization and general application of microeconomic theory with special focus on the competition policy issues.

Vladan Vučić, PhD is an assistant professor at the Faculty of Law, Security and Management "Konstantin Veliki", University Union-Nikola Tesla, Belgrade. He graduated and received his doctorate from the Faculty of Economics, University of Niš. He has a long career in the economy as a finance manager. $\mathrm{He}$ is a President of the Assembly of the Niš Association of Economists. He has published numerous scientific papers, and took part in many national and international scientific conferences. 
